\title{
Prospects and Ethical Concerns of Embryonic Stem Cells Research-A Review
}

\author{
C. S. Mukhopadhyay, Jayanti Tokas ${ }^{1}$ and P. D. Mathur
}

Guru Anand Dev Veterinary and Animal Science University, Ludhiana, Punjab, India.

1. Department of Biochemistry, COBS \& H, CCS-Haryana Agricultural University, Hisar

* Corresponding author email:csmbiotech@gmail.com

Published online at www.veterinaryworld.org on 25-03-2011

\begin{abstract}
Stem cell research has appeared as a silver lining of hope over the dark cloud of some untreatable diseases like cancer and certain neurological disorders. Embryonic stem cells, the tabula rasa, holds much promise in this regard owing to its totipotency, howbeit, it has whirled a severe tempest all over the world on the point of humanity. The present review article includes the chronology of stem cell research with special reference to the techniques that were evolved in due course of research, the controversy over the application of embryonic stem cells for therapeutics and present status of stem cell research under Indian context. India is being increasingly alluring the foreign companies to invest in this project since a huge prospect in stem cell marketing business is foreseen in this country.
\end{abstract}

Key words: Embryonic stem cells, markers, therapeutics, ethics, prospect in India.

\section{Introduction}

Stem cell research that has emerged as one of the most intriguing hierarchy of biological science is moving at a dazzling pace with an aim to address certain questions of medical problems (viz. organ transplantation, cancer research etc). Stem cells which are fundamentally of three types, viz., adult, embryonic and induced pluripotent stem cells, can be induced to transform into specialized cells under certain physiological and experimental conditions. The adult stem cells (ASC) are harbored in the adult tissues with the primary roles of maintenance and repair and have limited number of possible pathways to differentiate into cell types. Whereas the embryonic stem cells (ESC), derived from the inner cell mass (ICM) of preimplantation embryos (Evans and Kaufman, 1981), embryonic germ cells and fetal germ cells (Matsui et al., 1992, Resnick et al., 1992), can differentiate into many cell types. While the adult stem cells are only multipotent, ESC comes under the category of either being totipotent or pluripotent depending on the stage of harvesting the stem cells.

Embryonic stem cells popularly called as 'tabula rasa' as they typically exhibit little or no differentiation and are considered to possess more therapeutic potential than adult stem cells (Rossant and Nagy, 1999). By virtue of this property, ESC can form all the 220 types of cell found in the human body (including germ cells) (Placzek et al., 2009). A large numbers of embryonic stem cells can be easily grown in culture, while adult stem cells are rare in mature tissues and methods for expanding their numbers in cell culture are yet to be worked out (Cezar, 2007). The third kind of stem cells i.e. the induced pluripotent stem cells (iPSC) are specially treated ordinary cells (viz. skin cells) induced to exhibit some of the properties of embryonic stem cells. This branch of stem cell research is at puerile stage, howbeit, it seems to offer the advantages of embryonic stem cells without any ethical and rejection problems (Colman, 2008, Ellis et al., 2009). The present review encompasses the bases of embryonic stem cell research; its potential applications vis-à-vis associated ethical concerns.

\section{A Retrospect down the Time Line of Stem Cell Research}

The beginning of stem cell research dates back to the mid $19^{\text {th }}$ century with the discovery that some cells can procreate other cell types (Cooper, 2004). In the early $20^{\text {th }}$ century true stem cells were identified as progenitor of blood cells which led to administration of bone marrow through oral route to the anemic patients. Some sporadic research work in bone marrow transplantation in mice ultimately bid fair for allogenic transplantation in human being (Harris, 2009). A revolutionary discovery in immunogenetics by Jean Dausset (1958) unveiled that the histocompatibility antigens (Dausset et al., 1970), which enable our immune system to discern the self and non- 
self proteins, are the key to the graft rejection in human being and animals. Initially physicians performed bone marrow transplant between identical twins only. The first successful bone marrow transplantation between unrelated individual was performed in 1973 (Dupont, 1997). This marked the beginning of era of organ transplantation in human being, which also broached up some controversy over the validity of this technique from the viewpoint of mankind. In 1984, US Congress passed the National Organ Transplant Act to establish a national bone marrow donor registry vis-àvis to probe the graft acceptability (Verklan, 1993). The stem cell research started propelling at leaps and bounce thereafter. The first embryonic cell lines were developed from the inner cell mass by James Thompson (1998) at the University of Wisconsin Madison (Thomson et al., 1998).

\section{Isolation of Inner Cell Mass - the Source of Pluripotent Embryonic Stem Cells}

Isolation of the inner cell mass (ICM) is a crucial step while culturing embryonic stem cells (ESC). The first ever reported method to derive large quantities of pure ICM from the mouse blastocyst was by immunosurgical technique (Solter and Knowles, 1975) wherein the trophoblastic cells were stamped out by exposing them to rabbit antimouse serum followed by guinea pig complement-dependent antibody cytotoxicity. The immunosurgical isolation of ICM was successfully used in several species, like, mouse, rhesus monkey, swine and human embryos etc (Thomson et al., 1995, 1998, Wianny et al., 1997). In later years the immunosurgical isolation of ICM has gradually been replaced by some modified techniques due to its underlying problems like; it is labor intensive and involves possible risk of contamination. In a different technique, cultured mouse blastocysts were differentiated into giant trophoblastic cells and large egg-cylinder like structures. The later were subcultured to yield proliferating colonies of cells resembling ESC. This technique was further improved by placing the ICM on feeder layer (Wobus et al., 1984) to provide a coating of non-dividing cells that furnish a sticky surface to the inner cell mass and secretes a host of growth factors such as leukemia inhibitory factor (LIF) (Smith et al., 1988; Kakegawa et al., 2008). Subsequently a three step technique was devised to generate ESC like cell lines by trypsinizing the disaggregated rabbit blastocyst and plating onto murine and porcine embryonic fibroblast (MEF) feeder layer (Niemann and Strelchenko, 1994, Kim et al., 2007).

\section{In Search of Suitable Markers for Embryonic Stem Cells}

The embryonic stem cells have two important traits; the smallest amount of cytoplasm and fastest proliferation in the given population. In addition to the distinctive morphological features some additional markers of undifferentiated pluripotent cells also need to be investigated to confirm the authenticity of stem cell cultures. Alkaline phosphatase was used for the first time as a biochemical marker for bovine ESC (Kitiyanant et al., 2000). The embryonic stem cells are known to express a high specific activity of alkaline phosphatase which declines during progressive differentiation resulting in low ALP activities in somatic differentiated cells (Mueller and Tuan, 2008). Alkaline phosphatase activity has been detected in mouse, porcine and human ESC (Ginis et al., 2004, Kim et al., 2007). Alkaline phosphatase, along with SSEA-1, SSEA-3, SSEA-4, TRA-1-60 and TRA-1-81 antigens was detected by immunocytochemistry with specific primary antibodies in primate ESC line (Thomson et al., 1995). Besides several genomic markers namely, Oct4, Nanog, Stellar, and GDF3 have been identified as ESC marker-genes (Tay et al., 2008, Chiou et al., 2008). Researchers are presently characterizing the up- and down-regulation of such marker genes and their association with fatal diseases like cancer (Riekstina et al., 2009, Busch et al., 2008).

\section{Thrust Areas for Application of Embryonic Stem} Cells

ESC has tremendous application in varied fields, including human welfare and veterinary science. Totipotent ESC provide a powerful tool for the studies of early embryonic development (Wiles and Johansson, 1997, Rathjen et al., 1999), gene targeting (Lohnes, 1999), chimera formation (Qin et al., 2008), cloning (Stice and Keefer, 1993, Modlinski et al., 1996), transgenic animal production (Robl et al., 2007), gene therapy (Uzzaman et al., 2005) and regenerative medicine vis-à-vis drug designing (Brustle et al., 1997). Because of their potential use for targeted gene manipulation, isolation of ESC could have enormous potential not only for treating certain human diseases like Alzheimer's disease, diabetes, cancer, stroke, etc in human being, but various agricultural, biomedical and pharmaceutical applications also. Thorough understanding of the factors contributing to the establishment of ESC in vertebrate species, including human being would help treating certain diseases (Stice et al., 1996). The synthetic eggs obtained from culturing stem cells can 
be stripped of their own genetic material and used as a recipient for nuclei from desired adult somatic cell. After reprogramming they can develop to blastocyst stage and used to derive new ES cells. These cells in turn could be prompted to produce specific cell types for transplantation, to treat specific diseased conditions. Also these synthetic eggs can be used to obtain diseased tissues (by taking the nucleus from adult diseased tissue). Such ES cells would provide an unlimited source of diseased tissue allowing a better opportunity to study the disease in a better way. The study on stem cells also provides an opportunity to study the stem cell niche. The ability to grow pure populations of specific cell types offers a proving ground for chemical compounds that may have medical importance (Deng, 2010).

Treating the specific cell types with chemicals and measuring their response offers a short cut to sort out chemicals that can be used to treat the diseases that involve those specific cell types. Stem cell technology, therefore, would permit the rapid screening of hundreds of thousands of chemicals that must now be tested through much more time-consuming processes. Screening drugs by testing them on cultured embryonic stem cells could help reduce the risk of drug-related birth defects (http://www.guardian.co. uk/science/2007/oct/03/stemcells.animalrights). This could find an application in animal breeding, in overcoming germ cell tumors, in examining many complex processes including the roles of key genes and mechanisms underlying uniparental gene expression. The use of ESC technology in livestock may also overcome current limitation on efficient gene transfer by providing an abundance of totipotent stem cells to be genetically manipulated by using conventional recombinant techniques. As far as reproduction is concerned, obtaining germ cells from stem cells is exciting as well as helpful for treatment of infertility. The cultured germ cells may be used for cell-based therapies for reproductive disorders (Du and Taylor, 2009, Moore et al., 2008).

\section{Ethical Concerns}

When we consider stem cell ethics, we immediately find we are balancing what medical good might come from using embryonic stem-cell lines against the possible harm, not only to an embryo, but to a society that already may place too little value on human life. Stem cell research has become controversial because it focuses attention on moral and theological issues as well as medical ones. Use of embryonic stem cells for research involves the destruction of blastocysts formed from laboratoryfertilized human eggs. For those who believe that life begins at conception, the blastocyst is a human life and to destroy it is unacceptable and immoral (Robertson, 2001). Against this, embryonic research advocates argue that the tiny blastocyst has no human features (Romeo-Casabona, 2008). This seems to be the only controversial issue standing in the way of stem cell research in North America. Others argue against such research on medical grounds. Mice treated for Parkinson's with embryonic stem cells have died from brain tumors in as much as $20 \%$ of cases (Basu, 2006). Embryonic stem cells stored over time have been shown to create the type of chromosomal anomalies that create cancer cells (Cowan et al., 2004). Looking at it from a more pragmatic standpoint, funds devoted to embryonic stem cell research are funds being taken away from the other two more promising and less controversial types of stem cell research mentioned above. Currently, American federal funding can only go to research on stem cells from existing (already destroyed) embryos. Similarly, in Canada, as of 2002, scientists are not allowed to create or clone embryos for research and can only use those embryos that are discarded by couples voluntarily (Baylis and Herder, 2009)

\section{A Tug of War between Science and Conscience}

These ethical concerns over human embryonic stem cell research were sought as early as in 1973, when an abeyance was placed on government funding for human embryo research. Thereafter, various turbulence over this issue was observed in USA senate and also among the rank and file, both in for and against the use of human embryonic stem cells. In 2000, President Bill Clinton allowed funding of research on cells derived from aborted human fetuses, but not from embryonic cell. On August 9, 2001, President George W. Bush gave consent for Federal funding of research only on existing human embryonic stem cell lines created prior to his announcement (Anonymous, 2006). The elective victory over the issue of stem cell research funding organization initiative led to the establishment of "California Institute of Regenerative Medicine" in 2004 (Hall, 2007). In the summer of 2006, President Bush stood his ground on the issue of stem cell research and vetoed a bill passed by the Senate that would have expanded federal funding of embryonic stem cell research. Many American scientists were putting pressure on the government to allow ESC research and compete with the European counterpart involved in 
embryonic stem cell cloning. Very recently, present President of USA, Barack Obama modified the existing norm to use embryonic stem cells for research purpose as to use the embryonic cells that are disposed off from fertility clinics saying these words, "As a person of faith, I believe we are called to be for each other and work to ease human suffering. I believe we have been given the capacity and will to pursue this research..... and the humanity and conscience to do so responsibly"(http://www.reuters.com/article /idUSN0946466020090309). The restriction on funding to the stem cell research project imposed by President G. Bush in 2001 was lifted by present President Obama on $9^{\text {th }}$ March, 2009 and simultaneously assuring to craft strict guidelines for the same (Hutson, 2009, http://news.bbc.co.uk/2/hi/americas/ 7929690. stm). Very surprisingly, shares of the stem cell research company escalated upto $73 \%$ on the news.

Out of necessity, use of stem cell lines from alternative non-embryonic sources (viz. bone marrow, Umbilical-cord-derived stem cells) has received more attention in recent years and has already been demonstrated as a successful option for treatment of certain diseases and, with sufficient funding, other solutions might be found that are acceptable to everyone. Another option is use of uniparental stem cells. Although these cells lines have some disadvantages or shortcomings compared to embryonic cell lines (they are shorter-lived), there is vast potential if enough money is invested in researching them further, and they are not technically considered individual living beings by pro-life advocates. Biotech companies such as Revivicor and ACT are researching techniques for cellular reprogramming of adult cells, use of amnionic fluid, or stem cell extraction techniques that do not damage the embryo, that also provide alternatives for obtaining viable stem cell lines. On the contrary, one cannot overlook the returns provided by the embryonic stem cells, like their potentiality to make any variety of cells, immortality and readily available aspect (i.e. embryos from in-vitro fertilization clinics). Since, new stem cell lines already exist due to the common practice of in vitro fertilization, advocates of embryonic stem cell research uphold their claim that new human lives will not be created for the sole purpose of experimentation and thus embryonic stem cell continues to be the primary choice for the researchers (Baylis and Krahn, 2009).

\section{Stem Cell Research in I ndia}

The controversies that sprung up from the disputation over the hype and hope of stem cell therapy has also drawn the attention of the scientific community and visionary personages of India. The government has constituted cogent guidelines for installing a robust regulatory regime and a monitoring agency to augment competent stem cell research, due to the growing private and public healthcare centers, that claims stem cell treatment for a number of diseases. The department of biotechnology (DBT-GOI) and Indian Council of Medical Research (ICMR) in light of the above mandate published the guidelines for stem cell research and therapy in November 2007, addressing the ethical, scientific, legal and policy issues (Director General, ICMR. 2007).

India has commendable prospects in this arena in the coming years. Keeping in view its potential therapeutic applications, both basic and translational research are being promoted by the ICMR in various institutions, hospitals and the industry. Till date, more than 55 programmes have been identified and supported on various aspects of stem cell research like, generation of human embryonic stem cell lines, differentiation of pancreatic progenitor cells to insulin secreting cells, isolation of multi potential adult progenitor cells from bone marrow and their clonal expansion, etc (http://india.gov.in/sectors/science/ stem_cell_biology.php). Most of the renowned medical research institutes have come up to offer their finest in this domain. The All India Institute of Medical Sciences (AIIMS), New Delhi, had pioneered the treatment of heart problems using stem cells in India. The department of biotechnology (DBT-GOI), has commenced a mission on national stem cell research programme on "human embryonic stem cell" in collaboration with Indian Council of Medical Research (ICMR), in six cities across India (New Delhi, Bangalore, Pune, Mumbai, Hyderabad and Vellore) in the year 2004 (http://www.financial express.com/news/dbt-icmr-initiate-stem-cellresearch-programme/101293/).

The Armed Forces Medical College, Pune, has embarked on stem cell therapy for the first time, with an aim to regenerate the dead cardiac muscles following a heart attack. The Cardio Thoracic Centre at Military Hospital has already initiated the stem cell therapy on two patients with acute myocardial infraction, by injecting stem cells into the artery leading to the diseased organ (Chakraborty et al., 2009). The central government has sanctioned Rs 30 crore to the Christian Medical College, Vellore, to undertake a research project on stem cells. Apollo Hospitals Group has announced on 21st March' 2009, its plans to establish a Rs. 600 million project stem cell 
research institute in Ahmedabad, Gujarat in partnership with Cadila Pharmaceuticals and USbased Stem Cyte Inc, which is likely to start within one year (http://www.financialexpress.com/news/dbticmr-initiate-stem-cell-research-programme/ 101293/). Apart from the aforementioned endeavors in the area of stem cell research, some other attempts have also been taken by institutional departments and Governmental organizations to set up stem cell research laboratories.

A new horizon in animal biotechnology research was opened as National Dairy Research Institute (Karnal) has launched one NAIP project, named, "Characterization and differentiation of embryonic and spermatogonial stem cell in cattle and buffaloes" in partnership with Project Directorate of Cattle, Meerut with the basic objective of standardization of culture techniques and characterization of markers pertaining to spermatogonial and embryonic stem cells vis-à-vis testing their developmental competence in animal models (www.ndri.res.in/files/naip/naip3.pdf.)

\section{Conclusion}

Stem cell research holds promising approach in rendering a healing touch for some of the incurable diseases. Despite the concern pertaining to misuse of embryonic stem cell culture, a judicious approach has been taken by the Government of India and some other countries leading the ESC research. No doubt, this field has very bright prospect both in therapeutics and business in India and abroad. A study on the global market survey, Frost \& Sullivan (a consulting company), the stem cell therapy is expected to be $\$ 20$ billion by 2010. According to Satish Totey (Chief Operating Officer Stempeutics and Secretary of SCRFI), "India is expected to have a market share of about $\$ 540$ million by 2010 with an annual growth rate of 15 percent" (http://www.ncrm.org/media/ expresspharma15jun07.htm). Despite the challenges in this area starting from availability of human resource of desired expertise; adequate infrastructure; interdisciplinary network of researchers and clinicians, till appropriate regulatory mechanisms and well defined basic research, experts believe that the country can boast of a big platform for research and its clinical application, which merely any other country has.

\section{References}

1. Anonymous. (2006). Human Embryonic Stem Cell Research. Am. J. Respir. Crit. Care Med., 173: 1043-1045.

2. Basu, S. (2006). Regulating stem cell research in India: Wedding the public to the policy. Current Sci., 90(11): 1476-
1479

3. Baylis, F. and Krahn, T. (2009). The trouble with embryos. Sci.Studies, 22(2): 31-54.

4. Baylis, F. and Herder, M. (2009). Policy Design for Human Embryo Research in Canada: A History. J. Bioethic. Inquiry, 6(1): 109-122.

5. Brustle, O., Spiro, A. C., Karram, K., Choudhary, K., Okabe, S. and Mckay, R. D. (1997). In vitro-generated neural precursors participate in mammalian brain development. Proc. Natl. Acad. Sci.USA., 94: 14809-14814.

6. Busch, C., Oppitz, M., Wehrmann, M., Schweizer, P. and Drews, U. (2008). Immunohistochemical localization of nanog and Oct4 in stem cell compartments of human sacrococcygeal teratomas. Histopathol., 52(6): 717-30.

7. Cezar, G. G. (2007). Can human embryonic stem cells contribute to the discovery of safer and more effective drugs? Curr. Opin. Chem. Biol., 11(4): 405-409.

8. Chakraborty, C., Shieh, P. and Agoramoorthy, G. (2009). India's stem cell research and development perspectives. Int J. Hematol., 89(1):406-408.

9. Chiou, S.H., Yu, C.C., Huang, C.Y., Lin, S.C., Liu, C.J., Tsai, T.H., Chou, S.H., Chien, C.S., Ku, H.H. and Lo, J.F. (2008) Positive correlations of Oct-4 and Nanog in oral cancer stemlike cells and high-grade oral squamous cell carcinoma. Clin. Cancer Res., 14(13): 4085-4095.

10. Colman, A. (2008). Induced Pluripotent Stem Cells and Human Disease. Cell Stem Cell, 3(3): 236-237.

11. Cooper, M. (2004). Regenerative medicine: stem cells and the science of monstrosity. Med. Humanities, 30: 12-22.

12. Cowan, C. A., Klimanskaya, I., McMahon, J., Atienza, J., Witmyer, J., Zucker, J. P., Wang, S., Morton, C. C. McMahon, A. P., Powers, D. and Melton, D. A., (2004). Derivation of embryonic stem-cell lines from human blastocysts, New Engl J Med., 350(13): 1353-1356.

13. Dausset, J. (1958). Iso-leuco-anticorps. Acta. Haematol., 20 : 156-166.

14. Dausset, J., Rapaport, F. T., Legrand, L., Colombani, J. and Marcelli, B. (1970). Skin allograft survival in 238 human subjects: role of the specific relationship at the 4 gene sites of the first and the second HLA loci. In. Histocompatibility Testing, (Copenhagen, Munksgaard), 381-397.

15. Deng, W. (2010. Induced pluripotent stem cells: paths to new medicines. EMBO reports, $11: 161-165$.

16. Director General, ICMR. (2007). Guidelines for Stem Cell Research and Therapy. Published by Department of Biotechnology and Indian Council of Medical Research. Royal Offset Printers, New Delhi. (www.icmr.nic. in/stem_cell/stem_cell_guidelines.pdf).

17. Du, H. and Taylor, H. S. (2009). Stem cells and female reproduction, Reprod.Sci., 16(2): 126-139.

18. Dupont, B. (1997). Immunology of hematopoietic stem cell transplantation: a brief review of its history, Immunol. Rev., 157:5-12.

19. Ellis, J., Bruneau, B., Keller, G., Lemischka, I., Nagy, A., Rossant, J., Srivastava, D., Zandstra, P. and Stanford, W. (2009). Alternative Induced Pluripotent Stem Cell Characterization Criteria for In Vitro Applications. Cell Stem Cell, 4(3): 198-199.

20. Evans, M. J. and Kaufman, M. H. (1981). Establishment in culture of pluripotential cells from mouse embryos. Nature. 292: 154-156

21. Ginis, I., Luo, Y., Miura, T., Thies, S. and Brandenburg, R. (2004). Differences between human and mouse embryonic stem cells Dev Biol., 269: 360-380.

22. Hall, Z. W. (2007). California dreaming? A new start for 
regenerative medicine in the Golden State, Regen. Med., 2(1):25-28.

23. Harris, D. J. (2009). The resurgence of granulocyte transfusions. J. Infus. Nurs., 32(6): 323-9.

24. http://india.gov.in/sectors/science/stemcellbiology.php.

25. http://news.bbc.co.uk/2/hi/americas/7929690.stm.

26. http://www.financialexpress.com/news/dbt-icmr-initiatestem-cell-research-programme/101293/.

27. http://www.guardian.co.uk/science/2007/oct/03/ stemcells.animalrights.

28. http://www.ncrm.org/media/ expresspharma15jun07.htm.

29. http://www.reuters.com/article/idUSN0946466020090309.

30. Hutson, S. (2009). Challenges anticipated in removal of stem cell restrictions. Nat. Med., 15: 3 .

31. Kakegawa, R., Teramura, T., Takehara, T., Anzai, M., Mitani, T., Matsumoto, K., Saeki, K., Sagawa, N., Fukuda, K. and Hosoi, Y. (2008). Isolation and culture of rabbit primordial germ cells. J Reprod Dev., 54(5): 352-357.

32. Keim, B. (2007). 'Stem cell breakthrough is like "turning lead into gold", http://www. wired.com/medtech/stemcells/ news/2007/11/skin_cell.

33. Kim, H. S., Son, H. Y., Kim, S., Lee, G. S., Park, C. H., Kang, S. K., Lee, B. C. Hwang, W. S. and Lee, C. K. (2007). Isolation and initial culture of porcine inner cell masses derived from in vitro produced blastocysts. Zygote, 15(1): 55-63.

34. Kitiyanant, Y., Saikhun, J., Guocheng, J. and Pavasuthipaisit, K. (2000). Establishment and long-term maintenance of bovine embryonic stem cell lines using mouse and bovine mixed feeder cells and their survival after cryopreservation, Science Asia, 26: 81-86.

35. Lohnes, D. (1999. Gene targeting of retinoid receptors. Mol. Biotech., 11: 67-84.

36. Matsui, Y., Zsebo, K. and Hogan, B. L. M. 1992)(. Derivation of pluripotential embryonic stem cells from murine primordial germ cells in culture. Cell., 70: 841-847.

37. Moore, H., Udayashankara, R. and Aflatooniana, B. (2008). Stem cells for reproductive medicine. Mol Cell Endocrinol. 288(1-2): 104-110.

38. Mueller, M. B. and Tuan, R. S. (2008). Functional characterization of hypertrophy in chondrogenesis of human mesenchymal stem cells, Arthritis Rheum., 58(5): 13771388 .

39. Niemann, H. and Strelchenko, N. (1994). Isolation and maintenance of rabbit embryonic stem (ES) cell like cells, Therio., 41: 265.

40. Placzek, M. R., et.al. (2009). Stem cell bioprocessing: fundamentals and principles. J. R. Soc. Interface., 6(32): 209-232.

41. Qin, D., Gan, Y., Shao, K., Wang, H., Li, W., Wang, T., He, W., Xu, J., Zhang, Y., Kou, Z., Zeng, L., Sheng, G., Esteban, M. A., Gao, S. and Pei, D. (2008). Mouse meningiocytes express Sox2 and yield high efficiency of chimeras after nuclear reprogramming with exogenous factors, $J$ Biol Chem., 283(48): 33730-33735.

42. Rathjen, J., Lakes, J. A., Bettes, M. D., Washington, J. M., Chapman, G. and Rathen, P. D. (1999). Formation of primitive ectoderm-like cell population, EPL cells, from ES cell in response to biological derived factors. J. Cell Sci., 112: 601-612.

43. Resnick, J. L., Bixler, L. S., Cheng, L. and Donovan, P. J. (1992). Long-term proliferation of mouse primordial germ cells in culture. Nature, 359:550-551.

44. Riekstina, U., Cakstina, I., Parfejevs, V., Hoogduijn, M., Jankovskis, G., Muiznieks, I., Muceniece, R. and Ancans, J. (2009). Embryonic stem cell marker expression pattern in human mesenchymal stem cells derived from bone marrow, adipose tissue, heart and dermis. Stem Cell Rev., 5(4): 37886.

45. Robertson, J. A. (2001). Human embryonic stem cell research: ethical and legal issues, Nat. Rev. Genet., 2(1): 7478

46. Robl, J., Wang, Z., Kasinathan, P. and Kuroiwa, Y. (2007). Transgenic animal production and animal biotechnology. Therio., 67(1): 127-133.

47. Romeo-Casabona, C. M. (2008). Ethical, legal and social issues related to cell therapy. Law Hum. Genome Rev., 28 : 141-158.

48. Rossant J and Nagy A, Search of the tabula rasa of human cells. (1999). Nat. Biotechnol., 17(1): () 23-24.

49. Smith, A. G., Heath, J. K., Donaldson, D. D., Wong, G. G, Moreau, J., Stahl, M. and Rogers, D. (1988. Inhibition of pluripotential embryonic stem cell differentiation by purified polypeptides, Nature, 366: 688-690.

50. Solter, D. and Knowles, B. B. (1975). Immunosurgery of mouse blastocyst, Proc. Natl. Acad. Sci. USA., 72(12): 50995102

51. Stice, S. L and Keefer, C. L. (1993). Multiple generational bovine embryo cloning, Biol Reprod., 48: 715-719.

52. Stice, S. L., Strelchenko, N., Keefe, C, L, and Mathews, L. 1996. Pluripotent bovine embryonic stem cell lines direct embryonic development following nuclear transfer. Biol. Reprod., 54: 100-110.

53. Tay, Y., Zhang, J., Thomson, AM., Lim, B. and Rigoutsos, I. (2008). MicroRNAs to Nanog, Oct4 and Sox 2 coding regions modulate embryonic stem cell differentiation. Nat., 455(7216): 1124-8.

54. Thomson, J. A., Itskovitz-Eldor, J., Shapiro, S. S., Waknitz, M. A., Swiergiel, J. J., Marshall, V. S. and Jone,s J. M. (1998 Embryonic stem cell lines derived from human blastocysts. Science, 82(5391): 1145-1147. Erratum in: Science, 1998. 282(5395): 1827 .

55. Thomson, J. A., Kalishman, J., Golos, T. G., Durning, M., Harris, C. P., Becker, R. A. and Hearn, J. P. (1995). Isolation of a primate embryonic stem cell line. Proc. Natl. Acad. Sci. USA., 92: 7844-7848.

56. Uzzaman, M., Benveniste, R. J., Keller, G. and Germano, I M. (2005). Embryonic stem cell-derived astrocytes: a novel gene therapy vector for brain tumors, Neurosurg. Focus, 19(3): E6.

57. Verklan, M. T. (1993). The ethical use of fetal tissue for transplantation and research. J. Adv. Nurs., 18(8): 11721177.

58. Wianny, F. , Perreau, C. and Hochereau de Reviers, M. T. (1997). Proliferation and differentiation of porcine inner cell mass and epiblast in vitro. Biol. Reprod., 57: 756-764.

59. Wiles, M. V. and Johansson, B. M. (1997) Analysis of factors controlling primary germ layer formation and early hematopoiesis using embryonic stem cell in vitro differentiation. Leukemia., 11:454-456.

60. Wobus, A. M., Holzhausen, H., Jakel, P. and Schoneich, J. (1984). Characterization of a pluripotent stem cell line derived from a mouse embryo, Exp. Cell Res., 152: 212-219.

61. www.ndri.res.in/files/naip/naip3.pdf. 